\section{Effect of swimming training on stress-related metabolic parameters of diabetic and non-diabetic rats}

\section{Efeito do treinamento de natacão sobre estresse metabólico de ratos diabéticos e não diabéticos}

Eduardo Zapaterra Campos ${ }^{2}$

Aline Pincerato Jarrete ${ }^{2}$

Hygor Nunes de Araújo ${ }^{2}$

Suziane Ungari Cayres ${ }^{2}$

José Campanholi Neto

Dra. Eliete Luciano ${ }^{1,2}$

\begin{abstract}
Physical training can be an useful strategy to attenuate the stress markers concentrations and hyperglycemia on type 1 diabetic rats. Thus, the purpose of the present study was to investigate the effects of swimming training on metabolic parameters and stress markers in diabetic and non-diabetic rats. Twenty-four adult male Wistar rats were recruited. The rats were randomly divided into four groups, sedentary control (SC), trained control (TC), sedentary diabetic (SD), and trained diabetic (TD). The diabetic rats received alloxan monohydrate and the trained rats swam for 60 minutes five times per week. The training load was $3.5 \%$ and $5 \%$ of body weight to diabetic and non-diabetic rats, respectively. After the euthanasia, blood samples for determination of corticosterone, insulin, and glucose levels were collected, and the adrenal weight, adrenal cholesterol concentration, gastrocnemius glycogen concentration, and muscle total protein content were also determined. To compare the groups, a variance analysis was used with Tukey's post-hoc. The significance level of $5 \%$ was adopted. The adrenal weight was higher in SD $(17.2 \pm 0.6 \mathrm{~g})$ than the other groups (SC: $12.2 \pm 0.8 \mathrm{~g}$; TC: $13.7 \pm 0.6 \mathrm{~g}$; TD: $14.3 \pm 0.8 \mathrm{~g}$ ), and TD had similar values of TC. The corticosterone level of SD was higher than SC and TC. The serum glucose was higher in the diabetic groups and insulin was lower in these groups. Six weeks of swimming training was efficient to reduce stress markers concentration in type 1 rats. Training may be a good tool to avoid the reduction on muscle protein content in type 1 diabetic rats.
\end{abstract}

\section{KEYWORDS}

Stress; Diabetes; Exercise; Metabolism.

\section{RESUMO}

Treinamento físico pode ser uma estratégia útil para atenuar as concentrações de marcadores de estresse e biperglicemia em ratos diabéticos tipo 1. Assim, objetivo do estudo foi investigar o efeito do treinamento de natação sobre os parâmetros metabólicos e marcadores de estresse em ratos diabéticos e não diabéticos. Foram selecionados vinte e quatro ratos machos Wistar divididos em quatro grupos, controle sedentário (SC), controle treinado (TC), diabético sedentário (SD) e diabético treinado (TD). A indução de diabetes foi por aloxana monoidratada. Os ratos foram submetidos a 60 minutos de natação cinco vezes por semana com carga de 3,5\% e 5\% do peso corporal para ratos diabéticos e não diabéticos, respectivamente. Depois da eutanásia, foram determinados corticosterona, insulina, glicose, peso da adrenal, concentração de colesterol da adrenal e glicogênio do músculo gastrocnêmio e conteúdo proteico total muscular também foram determinados. Foi aplicada análise de variância e Post Hoc de Tukey, com significância estatística menor que $5 \%$. Peso da adrenal foi maior em $S D(17.2 \pm 0.6 \mathrm{~g})$ que nos outros grupos (SC: $12.2 \pm 0.8 g$; TC: $13.7 \pm 0.6 g$; TD: $14.3 \pm 0.8 g$ ) e TD apresentou valores similares de TC. A corticosterona de SD foi maior do que SC e TC. Glicose sérica foi elevada no grupo diabético e a insulina foi menor neste grupo. Seis semanas de treinamento de natação foram eficientes para reduzir a concentração de marcadores de estresse em ratos diabéticos tipo 1 . O treinamento de natação pode ser uma ferramenta útil para evitar a redução do conteúdo proteico muscular em ratos diabéticos tipo 1.

\section{PALAVRAS-CHAVE}

Estresse, Diabetes Mellitus Tipo 1, Exercício, Metabolismo
Rev Bras Ativ Fis Saúde p. 195-204 DOI:

http://dx.doi.org/10.12820/rbafs.v.19n2p195

1 Department of Physical Education. UNESP, Univ Estadual Paulista, Rio Claro, SP, Brazil.

2 Program of Pos-Graduate in Sciences

Motricity. Univ Estadual Paulista - UNESP, Rio Claro, São Paulo, Brazil. 


\section{INTRODUCTION}

Diabetes Mellitus is considered a worldwide health problem that affects about 347 millions of people, and there is an estimative that the prevalence of this disease will increase to 366 million people in $2030^{1}$. In 2004, about 3.4 millions of people died in consequence of hyperglycemia, and it is estimated that diabetes will be the seventh leading cause of death in $2030^{2}$.

This endocrine-metabolic disturbance is characterized by increased concentration of blood glucose, resulting from decreased or stoppage in insulin synthesis and secretion by pancreas, or from insulin resistance in peripheral tissues $^{3}$, which defines type 1 (DM1) and type 2 (DM2) diabetes, respectively. The absence or reduction of insulin action causes a sustained state of hyperglycemia, and increases serum concentration of free fatty acids and lipoproteins $^{3}$. Moreover, it alters the secretion and liberation of several hormones, resulting in changes in energetic metabolism ${ }^{3}$. Experimental models of diabetes, induced by chemical substances that damage the pancreatic cells, have been frequently used to simulate disease carriers ${ }^{3}$.

Physical exercise seems to be an important strategy to attenuate hyperglycemia in type 1 diabetic rats ${ }^{4}$ and promotes physiological and metabolic adjustments that ameliorate homeostasis ${ }^{5}$. These benefits of physical exercise can be observed after acute and chronic practice of exercise. Acute exercise can translocate the glucose transporter to the cell membrane independently of insulin action, which is mediated by muscle contraction ${ }^{6}$. This and other responses reflect a reaction to stress. Among these responses, the activation of the hypothalamic-pituitary-adrenal axis, that stimulates the releasing of adrenocorticotropic hormone (ACTH) deserves attention. The release of cortisol or corticosterone, the main glucocorticoid secreted by the cortex of the adrenal gland, is stimulated by ACTH and is directly involved in the homeostasis of energy metabolism ${ }^{7,8}$. However, even though physical training acutely increase catecholamine and cortisol, it seems that chronically, aerobic training decreases the releasing of $\mathrm{ACTH}^{8}$, and attenuates the hyperglycemia and other cardiometabolic alterations, even in rats treated with dexamethasone?

Previous studies have shown higher basal level of corticosterone in streptozotocin-diabetic rats compared with control group. However, this effect can be prevented by insulin replacement ${ }^{10}$. It is known that physical exercise can modulate the hormonal response of cortisol, and some authors consider this an important reaction in the adaptive response to stress ${ }^{11}$. Thus, exercise might be useful to promote a non-pharmacological control of glucose homeostasis and corticosterone release ${ }^{11}$. However, the potential effect of swimming training on hormonal (corticosterone) concentration, glucose metabolism and adrenal weight, and the relation between the stress markers concentration and metabolic parameters has not been assessed yet. Thus, the aim of the study was to investigate the effects of swimming training on metabolic parameters and stress markers in diabetic and non-diabetic rats and their relationships.

\section{METHODS}

\section{Animals}

Twenty-four adult male Wistar strain rats were recruited from the Central 
Animal Breeding House of São Paulo State University - UNESP, Botucatu, SP; and they were maintained at the Department of Physical Education, UNESP, Rio Claro, SP, Brazil. The rats were approximately 90days old at the beginning of the experiment. The animals were housed four per cage in a temperature-controlled room $\left(25 \pm 1^{\circ} \mathrm{C}\right)$ with a $12 / 12 \mathrm{~h} \mathrm{light/dark}$ cycle and free access to food and water.

Body weight was recorded at the beginning of the training and once a week until the day before the sacrifice. All experiments were performed in accordance with the European Convention for the Protection of Vertebrate Animals used for Experimental and other Scientific Purposes ${ }^{12}$. Study was approved by the research ethics committee of the Universidade Estadual Paulista "Julio de Mesquita Filho", Rio Claro/SP Campus, Brazil.

\section{Experimental groups}

The rats were randomly divided into four groups with 6 animals per group, as follows: sedentary control (SC), consisting of euglycemic rats that have not trained; trained control (TC), consisting of euglycemic rats that trained five days per week for $60 \mathrm{~min}$; sedentary diabetic (SD), consisting of alloxan induced diabetic rats that have not trained; and trained diabetic (TD), consisting of alloxan-induced diabetic rats that trained five days per week for $60 \mathrm{~min}$.

\section{Induction of diabetes}

For the induction of experimental diabetes, rats received alloxan monohydrate (Sigma) (32 $\mathrm{mg} / \mathrm{kg}$ body weight) dissolved in a $0.01 \mathrm{M}$ citrate buffer, $\mathrm{pH}$ 4.5 , and injected into the penile vein (20). After this procedure, the rats were relocated in cages, where they received glucose and water solution $(15 \%)$ and food ad libitum (19) for the first $24 \mathrm{hr}$. Five days after drug administration, a blood glucose test was made to confirm the diabetic state; and animals with blood glucose level equal to or greater than $150 \mathrm{mg} / \mathrm{dL}$ were identified as diabetic. The control group was injected with citrate buffer to be submitted to the same stress as the animals that received alloxan.

\section{Training Protocol}

Before the training period, the trained rats were adapted to the training environment to reduce stress levels. Rats were placed in individual 100x80x80 cm water tanks (water temperature $31 \pm 1^{\circ} \mathrm{C}$ ) for $1-10$ min daily over a period of 10 days before alloxan administration. Ten rats were adapted for time. Physical training began one week after alloxan administration ${ }^{13}$. The TC and TD were submitted to six weeks of aerobic training. The training consisted of 60 minutes of swimming, five times per week. The training load was equivalent to $3.5 \%$ of body weight for the diabetic rats $^{5}$ and $5 \%$ for the non-diabetic rats ${ }^{11}$

\section{Animal euthanasia and biological material collection}

At the end of the experiment, the animals were sedated in a $\mathrm{CO}_{2}$ chamber and euthanized by cardiac blood puncture, in accordance to previous studies ${ }^{10}$. The euthanasia in the trained groups was performance $\sim 48 \mathrm{~h}$ after the last exercise session.

The collected blood was centrifuged and the serum was used to determine the levels of glucose, insulin and corticosterone. Gastrocnemius muscle aliquots were weighed. These samples were used to determine the total protein 
content of gastrocnemius (TPG) and the concentration of glycogen (GG) of the gastrocnemius muscle. The subcutaneous adipose tissue was completely removed for the analysis.

\section{Analytical methods}

Glucose, insulin, and corticosterone levels were measured. The concentration of serum glucose (SGlu) was determined through the glucose oxidase method using commercial kits (Laborlab ${ }^{\circledR}$, Guarulhos, Brazil). The serum insulin levels (SIns) were assessed using radioimmunoassay (RIA, Kit Coat-A-Count, Los Angeles, USA). Serum corticosterone (SCort) was measured by the radioimmunoassay (RIA) with the use of the commercially available kit (DPC, Los Angeles, USA). All these procedures were conducted 48 hours after the euthanasia.

\section{Tissue analyzes}

Once removed and dissected on a filter paper moistened with saline the adrenal glands were weighed into an analytical balance. Then, the adrenal gland was removed and macerated for determining the content of ascorbic acid. The ascorbic acid concentration was measured $520 \mathrm{~nm}$ against a standard curve of ascorbic acid ${ }^{6}$.

For determination of the concentrations of total cholesterol in the adrenal gland, samples were homogenized in $1.5 \mathrm{~mL}$ of cooled chloroform/methanol mixed solution (2:1). Furthermore, $2.5 \mathrm{~mL}$ of cooled chloroform/methanol mixed solution $(2: 1)$ was added, and homogenized again and vortex-mixed. Lipid was extracted from homogenized samples overnight under refrigeration $\left(4^{\circ} \mathrm{C}\right)$. Total and free cholesterol in the adrenal gland were determined enzymatically using a commercially available Cholesterol-E test Wako kit (Wako Pure Chemical Industries, Osaka, Japan) and Free Cholesterol-E test Wako kit (Wako Pure Chemical Industries, Osaka, Japan), respectively. The amount of cholesterol ester was assumed to be the difference between total and free cholesterol. The total corticosterone levels were measured using RIA kits (DRG-Instruments, Marburg, Germany), according to the manufacturer's instructions.

The gastrocnemius sample was rapidly obtained, weighted, and frozen for glycogen and TPG analysis. For GG, after digestion in $1 \mathrm{~mL}$ of $30 \% \mathrm{KOH}$ for $60 \mathrm{~min}$ in a warm bath, precipitation of glycogen was performed in $0.1 \mathrm{~mL}$ saturated $\mathrm{Na}_{2} \mathrm{SO}_{4}$ solution and $3.5 \mathrm{~mL}$ ethanol, following the dosage according to the method of DuBois et $\mathrm{al}^{14}$. The dosage of total protein content of gastrocnemius (TPG) was performed according to the method of Bradford ${ }^{15}$.

\section{Statistical analysis}

The numerical variables are presented as mean and standard deviation (SD). Firstly, Levene's test was applied, and afterwards, the one-way variance analysis (ANOVA) was used to compare the sample groups (SC; TC; SD and TD). If necessary, the post-hoc of Tukey was used. The association between stress markers and metabolic parameters was assessed by Pearson correlation. A significance level of $5 \%$ was adopted. Statistical analyses were carried out using the software Statistical Package for Social Science (SPSS®: version 13.0).

\section{RESULTS}

The sample consisted of 24 male Wistar rats (60 days life) and 6 animals were 
allocated in each group. Table 1 presents metabolic and hormonal parameters measured after six weeks of study in the four groups. The adrenal weight was higher in SD compared with all the other groups, and the TD had an adrenal weight similar to the TC.

After six weeks, the SD presented lower weight, and GG than other groups and lower TPG than TC. Both control groups showed higher Peri-epididymal concentration than diabetic groups (Table 1).

Serum glucose was elevated in the diabetic groups (SD: $299.5 \pm 25.2 \mathrm{mg}$ / $\mathrm{dL}$ and TD: $265.4 \pm 26.6 \mathrm{mg} / \mathrm{dL}$ ) compared with the control groups (SC: $119.9 \pm 5.0 \mathrm{mg} / \mathrm{dL}$ and TC: $113.8 \pm 7.6 \mathrm{mg} / \mathrm{dL}$ ) (Figure 1A). Furthermore, serum insulin of the SD and TD $(9.3 \pm 0.9$ and $9.5 \pm 0.8 \mu \mathrm{UI} / \mathrm{mL}$, respectively) were significantly lower than the SC and TC $(19.55 \pm 0.6 \mu \mathrm{UI} / \mathrm{mL}$ and $17.6 \pm$ $0.8 \mu \mathrm{UI} / \mathrm{mL}$, respectively) (Figure 1B). Serum corticosterone of the SD (283.5 $\pm 41.1 \mathrm{ng} / \mathrm{mL}$ ) was significantly elevated than the control groups (SC: $220.3 \pm$ $14.2 \mathrm{ng} / \mathrm{mL}$; TC: $225.9 \pm 18.8 \mathrm{ng} / \mathrm{mL}$ ), while serum corticosterone of the TD $(249.5 \pm 31.2 \mathrm{ng} / \mathrm{mL})$ did not differed from all the other groups (Figure 1C).

Serum glucose concentration presented a positive correlation with corticosterone and adrenal weight, while serum insulin concentration presented a negative correlation with corticosterone and adrenal weight (Table 2).

TABLE 1 - Metabolic and hormonal parameters measured after six weeks of the study in male Wistar control and diabetic rats evaluated after 48 hours rest.

\begin{tabular}{lcccccc}
\hline & $\begin{array}{c}\text { SC } \\
(\mathrm{n}=6)\end{array}$ & $\begin{array}{c}\text { TC } \\
(\mathrm{n}=6)\end{array}$ & $\begin{array}{c}\mathrm{SD} \\
(\mathrm{n}=6)\end{array}$ & $\begin{array}{c}\text { TD } \\
(\mathrm{n}=6)\end{array}$ & $\mathrm{F}$ & $p$-value \\
\hline Body weight $(\mathrm{g})$ & $359.6 \pm 8.7$ & $332.5 \pm 22.8$ & $281.3 \pm 30.1^{\mathrm{a}, \mathrm{b}}$ & $334.6 \pm 25.3^{\mathrm{c}}$ & 12.6 & $0.00^{*}$ \\
\hline Adrenal weight $(\mathrm{g})$ & $12.2 \pm 0.8$ & $13.7 \pm 0.6^{\mathrm{a}}$ & $17.2 \pm 0.6^{\mathrm{a}, \mathrm{b}}$ & $14.3 \pm 0.8^{\mathrm{a}, \mathrm{c}}$ & 36.0 & $0.00^{*}$ \\
\hline $\begin{array}{l}\text { Adrenal chol } \\
\text { (mg/100g) }\end{array}$ & $1.4 \pm 0.3$ & $1.6 \pm 0.2$ & $1.2 \pm 0.2$ & $1.8 \pm 0.2^{\mathrm{c}}$ & 4.6 & $0.01^{*}$ \\
\hline Adrenal AA $(\mu \mathrm{g} / \mathrm{mg})$ & $8.1 \pm 0.6$ & $6.6 \pm 0.5^{\mathrm{a}}$ & $5.7 \pm 0.4^{\mathrm{a}}$ & $6.0 \pm 0.6^{\mathrm{a}}$ & 21.0 & $0.00^{*}$ \\
\hline GG (mg/100g) & $0.6 \pm 0.0$ & $0.7 \pm 0.0^{\mathrm{a}}$ & $0.5 \pm 0.0^{\mathrm{a}, \mathrm{b}}$ & $0.7 \pm 0.0^{\mathrm{a}, \mathrm{c}}$ & 19.2 & $0.00^{*}$ \\
\hline TPG (mg/100g) & $8.7 \pm 0.7$ & $9.3 \pm 0.6$ & $7.6 \pm 0.5^{\mathrm{b}}$ & $8.6 \pm 0.7$ & 5.8 & $0.00^{*}$ \\
\hline $\begin{array}{l}\text { Peri-epididymal } \\
\text { (mg/100g) }\end{array}$ & $307.3 \pm 29.2$ & $285.5 \pm 15.0$ & $75.0 \pm 20.6^{\mathrm{a}, \mathrm{b}}$ & $84.6 \pm 15.3^{\mathrm{a}, \mathrm{b}}$ & 216.1 & $0.00^{*}$ \\
\hline
\end{tabular}

\#Mean \pm SD; SC - sedentary control; TC - trained control; SD - sedentary diabetic; TD -trained diabetic; Chol - total cholesterol; AA - ascorbic acid; GG - gastrocnemius glycogen; TPG - total
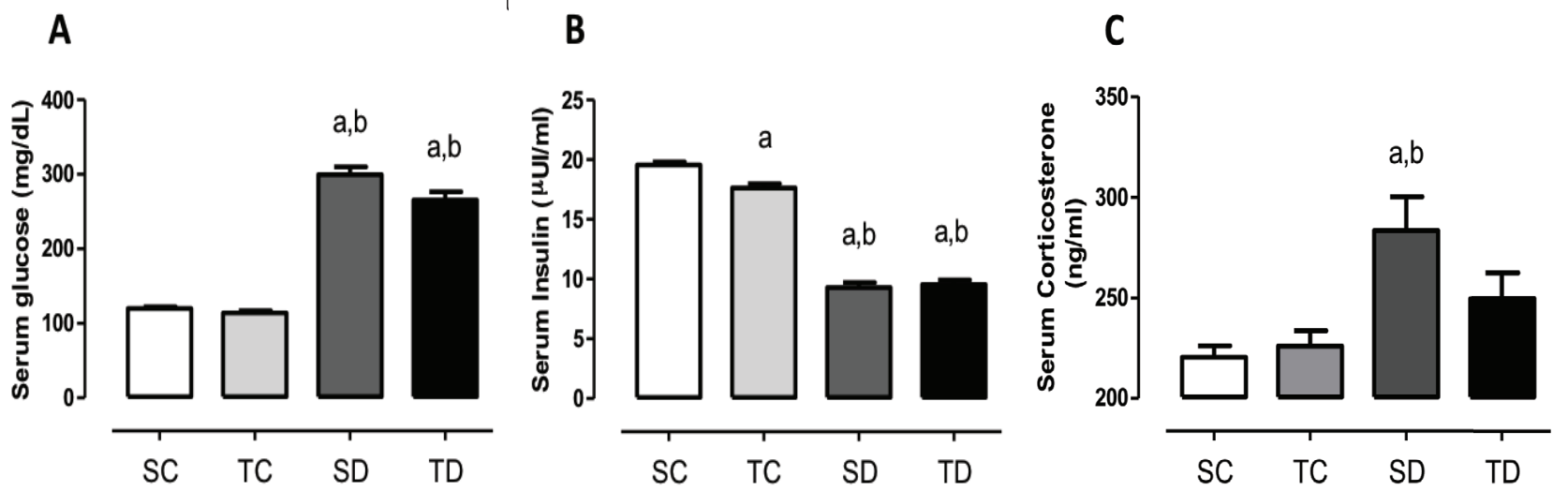

FIGURA 1 - Serum glucose (panel A), serum insulin (panel B) and serum corticosterone (panel C) measured in the 4 groups: sedentary control (SC), trained control (TC), sedentary diabetic (SD) and trained diabetic (TD), $a \neq S C ; b \neq T C ; c \neq S D$. 
TABLE 2 - Correlation coefficients ( $r$ ) between stress markers with metabolic parameters in nondiabetic and diabetic rats exposed or not to swimming training $(n=24)$.

\begin{tabular}{lll}
\hline Metabolic parameters & Stress Markers & \\
\hline Glucose $(\mathrm{mg} / \mathrm{dL})$ & $\begin{array}{l}\text { Corticosterone } \\
(\mathrm{ng} / \mathrm{mL})\end{array}$ & $\begin{array}{l}\text { Adrenal Weight } \\
(\mathrm{g})\end{array}$ \\
\hline Insulin $(\mu \mathrm{UI} / \mathrm{mL})$ & $0.59^{*}$ & $0.73^{*}$ \\
\hline
\end{tabular}

$*$ p-value $<0.05$

\section{DISCUSSION}

The purpose of the present study was to analyze the effect of six weeks of training on stress-related metabolic and hormonal parameters in controlled and diabetic rats, and their relationships.

Figures $\mathrm{A}$ and $\mathrm{B}$ show that the alloxan was effective in inducing type 1 diabetes, as has already been shown by Arantes et al. ${ }^{11}$. The serum glucose of the diabetic groups was significantly higher than both SC and TC. These results agree with the study of Repetto et $\mathrm{al}^{6}$. The SD and TD groups had decreased insulin concentrations compared with SC and TC. Training did not attenuate hyperglycemia in diabetic groups.

The GG was significantly higher on the training groups (TC and TD) compared with the sedentary groups (SD and SC). Our finding is consistent with the literature that points out reduced muscular glycogen concentration due to reduced glucose uptake in type 1 diabetes ${ }^{16}$. However, training stimulus seemed to promote a positive adaptation on glucose uptake even in diabetic rats. This finding is in line with Bak et al. ${ }^{17}$ who demonstrated increase of glycogen synthase activity in type 1 diabetes after training, even without enhancing insulin receptor function. Probably, the role of exercise in increasing glucose uptake ${ }^{18}$ may be the reason for this result. Manabe et al. ${ }^{19}$ have shown that training increases both the level of GLUT4 protein (major glucose transporter in skeletal muscle) and the glycogen synthase activity. The explanation for the increase of glycogen content is the augmentation of the major signaling proteins that regulate glycogen synthase (i.e. protein phosphatase 1 and glycogen synthase kinase $)^{20}$.

The total protein content in gastrocnemius (TPG) was significantly reduced in SD compared with the other groups. Due to the association between type 1 diabetes and lower levels of insulin growth factor ${ }^{20}$ and growth hormone ${ }^{21}$, and their close relationship with muscle hypertrophy ${ }^{22}$, the SD presented a reduced TPG. However, the training was effective in increasing the TPG in TD. The increase in glycogen content and the swimming stimulus during the training could be a reason for the increase of TPG in $\mathrm{TD}$, since mRNA of genes implicated in the regulation of hypertrophy are reduced when muscle glycogen content is $l_{0 w^{22-24}}$. It is known that even aerobic swimming stimulates growth hormone/insulin growth factor- 1 in type 1 diabetic rats ${ }^{19}$. Although this study did not attempt to study molecular mechanisms, the effect of increased insulin growing factor activity after training could account for the muscle modifications.

The main findings of the study were the significant lower adrenal weight of the trained groups (TC and TD) and SD compared with the SC, and the sig- 
nificant higher serum corticosterone of the SD group compared with SC and TC. The adrenal gland plays a central role in the pathophysiology of stress by releasing cortisol (human) or corticosterone (rodents) into the circulatory system. Normally, glucocorticoids inhibit the hypothalamic-pituitary-adrenal axis (negative feedback) ${ }^{24}$. In the present study, the SD adrenal weight was higher than all other groups, suggesting a hypertrophy of the gland due to the diabetes. This result agrees with others authors ${ }^{24}$. The reason for this might be that in diabetics rats, the glucocorticoids negative feedback is impaired, increasing the action of the hypothalamic-pituitary-adrenal axis ${ }^{25}$, and leading to adrenal hypertrophy.

The increased values of serum corticosterone in SD might be related to the inflammatory status of diabetic rats. Regarding this aspect, Martín-Cordero et al. ${ }^{26}$ have stated that the elevation of interleukin-6 (IL-6) stimulates corticosterone release. Despite a non significant difference between corticosterone in TD and SD, the mean corticosterone value was $12 \%$ lower in TD than SD, suggesting that previous training had some effect reducing stress markers. Previous studies showed that IL- 6 concentration was higher in obese rats after training ${ }^{26}$, however, muscle-derived IL-6 seems to be a true anti-inflammatory "exercise factor", protecting against insulin resistance, and enhancing glucose infusion rate ${ }^{27}$. Thus, aerobic training may reduce systemic inflammation and, consequently, the corticosterone concentration ${ }^{26,27}$.

Besides the positive effects of physical training, typical stress-induced responses are also described after physical training, specially its influence over the adrenal activity ${ }^{28}$. Bartalucci et $\mathrm{al}^{28}$ verified increases in the adrenal gland size of mice after two types of training (high and low intensity). The mice that trained at higher intensity presented $31.04 \%$ of increase in adrenal size compared to $10.08 \%$ increase in the low intensity group. This result suggests the influence of training intensity on the adrenal weight response to training. The present study observed that the TD had lower adrenal weight than SD, showing a positive effect of exercise training on modulating the adrenal activity, and leading to the same adrenal weight of the TC. Taking this finding together with the absence of difference between the serum corticosterone of SC, TC and TD (Figure 1C) evidence that aerobic swimming training was effective to reduce the stress on the adrenal gland in diabetic rats.

The present study observed a difference on total cholesterol at the adrenal gland between TD and SD, while no difference was verified between the control groups. In rats, cholesterol content after 3-weeks of swimming training associated with dexamethasone supplementation was reduced compared with control animals, however dexamethasone alone reduced even more the cholesterol content ${ }^{29}$, which suggests an effect of the exercise on the liberation of corticosterone. The cholesterol content might be useful to detect overload on adrenal gland due to increased glucocorticoid release, since cholesterol is a glucocorticoid precursor ${ }^{29}$. The higher cholesterol content on the TD is not in accordance with recent results ${ }^{29}$ that verified increased adrenal weight and cholesterol content in psychosocial stressed mice. Thus, training might have a different impact on adrenal cholesterol when diabetes is induced.

Ascorbic acid (AA) is essential for catecholamine production since it was demonstrated that the deficiency of AA in mice induced a reduction of norepinephrine and epinephrine ${ }^{30}$. Padayatty et al. ${ }^{31}$ have demonstrated that ad- 
renocorticotrophic (ACTH) hormone stimulation increases Vitamin C concentration at adrenal vein. The present study showed that adrenal AA was significantly higher in the SC than the other three groups (Table 1). Thus, adrenal AA may reflect the stimulation of ACTH on adrenal gland in sedentary rats. On the other hand, mutant mice lacking the plasma membrane AA transporter (SVCT2) have severely reduced tissue levels of AA and die soon after birth. There is a significant decrease of tissue catecholamine levels in the adrenals. In the present research, SD presented reduced adrenal AA beside higher weight of the gland, suggesting a damage in plasma membrane of diabetic rats and minor processes of hormonal synthesis through the AA, but the last might have induced adrenal hypertrophy. On the other hand, physical training may attenuated these effects on diabetic rats.

One of the main findings of the present study is the relationship between stress markers (corticosterone and adrenal weight) and metabolic parameters (glucose and insulin). The higher glucose concentration, the higher is corticosterone level and adrenal weight. Thus, there is a relationship between stress and metabolic parameters in rats. Trained diabetic rats have higher (not significantly different) corticosterone levels than SC and TC, evidencing that, even with training (six weeks), the diabetes still influences his stress-related status (corticosterone). However, although not significantly different, the glucose, insulin, and corticosterone level on TD is lower than SD. Probably, a longer training period could evidence statistical differences between TD and $\mathrm{SD}$, highlighting that trained diabetic rats could have more similar stress-related status than sedentary control or, even, trained control.

This study is limited by the sample size of each group, and the difficulty of extrapolating results directly to humans. Furthermore, even though six weeks can promote benefits on metabolic and stress markers in type 1 diabetic rats, probably, a longer period of training could demonstrate higher differences between the groups.

Thus, we conclude that six weeks of swimming training was able to reduce the stress related metabolic parameters induced by type 1 diabetes in rats. In addition, this training prevents the reduction on muscle protein content and enhances muscle glycogen content of diabetic rats.

\section{Competing interests}

The authors declare that they have no competing interests.

\section{Contribution of the Authors}

EZC: draft of the article and selection of manuscripts to discuss the results; APJ and HNA: selection of manuscripts to introduce and discuss the results; SUC: acquisition, analysis and interpretation of data; JCN: selection of manuscripts to discuss the results; EL: conception and design of the study, review and approval of the final version to be submitted. All authors read and approved the final manuscript.

\section{Acknowledgements}

The authors would like to thank the Rômulo A. Fernandes and Alexandre R. Spagnol from the Post-Graduate Program in Movement Sciences, UNESP, Rio Claro Campus, for their essential support this paper. 


\section{REFERENCES}

1. Wild S, Roglic G, Green A, Sicree R, King H. Global Prevalence of Diabetes Estimates for the year 2000 and projections for 2030. Diabetes Care. 2004 May; 27(5): 1047-1053.

2. WHO. World Health Organization. Diabetes: Fact sheet $N^{\circ} 312$, Key facts. Available at: http://www.who.int/mediacentre/factsheets/fs312/en/index.html. Acessed on: May, 2013.

3. Creager MA, Lüscher TF. Diabetes and vascular disease Pathophysiology, clinical consequence, and medical therapy: Part I. Circulation. 2003 Set; 108: 1527-1532.

4. Rocha RE, Coelho I, Pequito DC, Yamagushi A, Borghetti G, Yamazaki RK et al. Interval training attenuates the metabolic disturbances in type 1 diabetes rat model. Arq Bras Endocrinol Metabol. 2013 Nov;57(8):594-602.

5. Moura L, Bertolini N, Ghezzi AC, Bertucci D, Bonfim M, Serafim TH et al. Glucose Homeostasis in Type 1 Diabetic Rats after Acute Physical Activity. JEP online. 2011 Dec; 14(6): 8-19.

6. Repetto EM, Sanchez R, Cipelli J, Astort F, Martinez C, Piroli GG et al. Dysregulation of Corticosterone Secretion in Streptozotocin-Diabetic Rats: Modulatory Role of the Adrenocortical Nitrergic System. Endocrinology. 2010 Jan; 151(1): 203-210.

7. Hackney AC. Exercise as a stressor to the human neuroendocrine system. Medicina (Kaunas). 2006; 42(10): 788-97.

8. Pauli JR, Gomes RJ, Luciano E. Hypothalamo-pituitary axis: effects of physical training in rats administered with dexamethasone. Revista de neurologia, 2006;42(6):325-31.

9. Pinheiro CH, Sousa Filho WM, Oliveira Neto J, Marinho Mde J, Motta Neto R, Smith $\mathrm{MM}$, et al. Exercise prevents cardiometabolic alterations induced by chronic use of glucocorticoids. Arquivos brasileiros de cardiologia. 2009;93(4):400-8, 392-400.

10. Oliveira CAM, Paiva MF, Mota CAS, Ribeiro C, Leme JACA, Luciano E. Exercise at anaerobic threshold intensity and insulin secretion by isolated pacreatic islets of rats. Islets, 2010;2:4,240-246.

11. Arantes LM, Bertolini NO, De Moura RF, De Mello MAR, Luciano E. Insulin concentrations in cerebellum and body balance in diabetic male rats: Aerobic training effects. Physiology \& Behavior. 2013; 118: 58-62, 2013.

12. AVMA. American Veterinary Medical Association. Guidelines for the Euthanasia of Animals: 2013 Edition.

13. Luciano E, Lima FB. Metabolismo de ratos diabéticos treinados submetidos ao jejum e ao exercício agudo. Rev Ciênc Bioméd 1997;18:47-60.

14. Dubois, B., Gilles, K.A., Hamilton, J.K., Rebers, P.A., 1956. Colorimetric method for determination of sugar and related substances. Anal. Chem. 28, 350-356.

15. Bradford, M.M. A rapid and sensitive method for the quantitation of microgram quantities of protein utilizing the principle of protein dye binding. Anal. Biochem. 1976. 72 : 248-254.

16. Koivisto VA, Yki-järvinen H. Changes in muscle glucose metabolism in type 1 diabetes. Ann. Med. 1990 Jun; 22(3): 201-5.

17. Bak JF, Jacobsen UK, Jorgensen FS, Pedersen O. Insulin Receptor Function and Glycogen Synthase Activity in Skeletal Muscle Biopsies from Patients with InsulinDependent Diabetes Mellitus: Effects of Physical Training. Journal of Clinical Endocrinology \& Metabolism. 1989;69(1):158-64.

18. Fueger PT, Shearer J, Bracy DP, Posey KA, Pencek RR, McGuinness OP et al. Control of muscle glucose uptake: test of the rate-limiting step paradigm in conscious, unrestrained mice. J Physiol. 2005 Dec; 562(3): 925-935.

19. Manabe Y, Golllisch KS, Holton L, Kim YB, Brandauer J, Fujii NL et al. Exercise training-induces adaptations associated with increases in skeletal muscle glycogen content. The FEBS Journal. 2013 Jan; 280(3): 916-926.

20. Gomes RJ, de Mello MA, Caetano FH, Sibuya CY, Anaruma CA, Rogatto GP et al. Effects of swimming training on boné mass and the GH/IGF-1 axis in diabetic rats. Growth Horm IGF Res. 2006 Oct; 16(5-6): 326-331.

21. Chiarelli F, Giannini C, Mohn A. Growth, growth factors and diabetes. Eur J Endocrinol. 2004; Nov 151 (Suppl 3): U109-117. 
22. Glass DJ. Molecular mechanisms modulating muscle mass. Trends Mol Med. 2003 Aug; 9 (8): 344-350.

23. Creer AGP, Slivka D, Jemiolo B, Fink W, Trappe S. Influence of muscle glycogen availability on ERK1/2 and Akt signaling following resistance exercise in human skeletal muscle. J Appl Physiol 99: 950 -956, 2005.

24. Churchley EG, Coffey VG, Pedersen DJ, Shield A, Carey KA, Cameron-Smith D, Hawley JA. Influence of preexercise muscle glycogen content on transcriptional activity of metabolic and myogenic genes in well-trained humans. J Appl Physiol 102: $1604-1611,2007$.

25. Smith SM and Vale WW. The role of the hypothalamic-pituitary-adrenal axis in neuroendrocrine responses to stress. Dialogues Clin Neurosci. 2006; 8(4): 383-395.

26. Martín-Cordero L1, García JJ, Hinchado MD, Ortega E. The interleukin-6 and noradrenaline mediated inflammation-stress feedback mechanism is dysregulated in metabolic syndrome: effect of exercise. Cardiovasc Diabetol. 2011,20;10:42.

27. Pedersen BK, Åkerström TC, Nielsen AR, Fischer CP. Role of myokines iin exercise and metabolism. J Appl Physiol 103: 10093-1098, 2007.

28. Bartalucci A, Ferruci M, Fulceri F, Lazzeri G, Lenzi P, Toti L, Serpiello FR, La Torre A, Gesi M. High-intensity exercise trainin produces morphological and biochemical changes in adrenal gland of mice. Histol Histopathol. 2012 Jun; 27 (6): 753-769.

29. Füchsl Am, Uschold-Schmidt N, Reber SO. Chronic psychosocial stress in male mice causes and up-regulation of scavenger receptor class $\mathrm{B}$ type 1 protein in the adrenal glands. Stress. 2013 Jul; 16(4): 441-468.

30. Amano A, Tsunoda M, Aigaki T, Maruyama N, Ishigami A. Effect of ascorbic acid deficiency on catecholamine synthesis in adrenal glands of SMP30/GNL knockout mice. Eur J Nutr. 2013 Mar; 19. Epub ahead of print.

31. Padayatty SJ, Doppman JL, Chang R, Wang Y, Gill J, Papanicolaou DA, et al. Human adrenal glands secrete vitamin $\mathrm{C}$ in response to adrenocorticotrophic hormone. Am J Clin Nutr. 2007 Jul; 86(1): 145-149.

CORRESPONDING AUTHOR

SUZIANE UNGARI CAYRES

Universidade Estadual Paulista,

Departamento de Educação Física.

Rua Roberto Simonsen 305, Presidente

Prudente, SP. CEP: 19060-900.

Tel. (18) 32295828.

E-mail: suziungaridyahoo.com.br 